\title{
Thematic Concerns in Zora Neale Hurston's Their Eyes Were Watching God
}

\author{
Dr. Prasanta Kumar Padhi \\ Department of English, Orissa Engineering College
}

\begin{abstract}
Their Eyes Were Watching God is generically the kind of novel called a bildungsroman, a German term that means "novel of education," which describes the formation of the protagonist's mind and character from youth into maturity. The journey of discovery that Janie undertakes begins at the gatepost of her grandmother's house, and ends in the bedroom of the house she has inherited from a 20-year marriage. Each of the major plot developments occurs as a departure from a house. Each man she takes up with enriches her knowledge of the world, so at the end of the novel, Janie returns to her former home. Hurston, in Their Eyes Were Watching God projected a model for the Afro-American women who were seeking their voice and self. Afro-American women were disillusioned by two reformist movements in the 1960s: Women's Liberation and civil rights movements. Most white feminists showed little interest in the race problem and most male AfroAmericans stuck to their sexist ideas on women's role. As a result, in the movements in which it should be essential to raise a voice, Afro-American women found themselves degenerated into voice less existence and keenly realized the necessity to regain their own voice. Creating Janie Crawford, the protagonist of Their Eyes Were Watching God, Hurston projected black women as powerful, articulate, self-reliant, and radically different from any women character they had ever encountered in literature.
\end{abstract}

Key words: Resistance, domination, community, pertinent, denounce

Before the civil war in America, the Black African people were treated as chattels and were subjected to all kinds of injustice and social discrimination. But the real victims were the black African women, as these women had no position in society and were living the most pathetic and humiliating life. For a long time these black women were treated as beasts of burden in the white patriarchal society and treated as mammy. These women were ill treated first by their own male members in their own homes and secondly they were subjugated to all kinds of humiliating position by the white population. They had no honor or any sense of right as they were kept in complete ignorance and darkness for a long time.

The civil rights movement that started in the sixties in America brought in a new awareness in the society of black African people and created an atmosphere of search for their civil rights and position in their society. These people for the first time become conscious of the principles of human rights and began to feel the social injustice and inequality inflicted on them. This ushered in at the same time a new renaissance in the field of literature by black writers in general and black women writers in particular. These black women writers emerged with an assertive spirit to celebrate the importance of black womanhood in their writings. Their intensity of feeling and discrimination were projected in their novels written during the period 1970 to 1980 . Many Black women writers have adopted Alice Walker's term, 'womanist', to describe the unique realities they face in the contemporary society. Womanists have questioned the ways in which knowledge is passed down and how the dominant, white culture has stamped out language, tradition, and history along with women's voices. African-American writers like Alice Walker, Toni Morrison, Zora Neale Hurston and Gloria Anzaldua, have reclaimed their African heritage and the voice of resistance within slavery as they have struggled to hear the women's harmony through their writings.

Among all these black women writes the first woman who caught the eyes of all the rising feminist writers of 60's and 70's is Zora Neale Hurston. Commenting on the importance of Huston at their time, Henry Louis Gates in his book The Signifying Monkey: A Theory of African American Literary Criticism observed:

Zora Neale Hurston is the first writer that our generation of black and feminist critics has brought into the canon, or perhaps I should say the cannons. For Hurston is now a cardinal figure in the Afro American cannon, and the canon of Afro American fiction, especially as our readings of her work become increasingly close readings, which Hurston's texts sustain delightfully. The curious aspects of widespread critical attention being shown to Hurston's texts is that so many critics embracing such a diversity of theoretical approaches seem to find something new at which to marvel in her texts. (Gates, 180) 
All her novels are generally characterized by her autobiographical elements which have gone deep into her fiction. This is because she draws the material from her own experiences and the socio economic condition of the black woman in general, in all her works. An objective study of her second novel Their Eyes are Watching God, reveals that this work has its roots in her autobiographical work. As Hurston comment s on the supremacy of white masters:

The devil is not the terror that he is in European folklore. He is a powerful trickster who often competes successfully with God. There is a strong suspicion that the devil is an extension of the story maker while God is the supposedly impregnable white masters, who are nevertheless defeated by the negroes.(Hurston, 307)

Coming to the significance of the title of the novel, we find that it strikes us as strange when it becomes apparent that the story is about one woman rather than the "their" mentioned in the title. The reference to the title comes when there is a hurricane on the "muck". The seasonal workers in the community are debating whether or not to leave the area: "they seemed to be staring in the dark, but their eyes were watching God". It is not suggesting that the "God" of the passage is the white man; certainly the concept of Supreme Being governing humanity is present in the novel. But Hurston gives a second reading of "God" which indicates that it may refer not only to an absolute spirit but to the white hegemony. In the section describing the hurricane in the Florida everglades, numerous references are made to God as "bossman" and "Ole Massa" God appears at times as capricious slave master whose whims and dangerous acts are incontrollable. Yet Hurston constantly keeps her readers aware of the duality of the Christian God for the black folks as they make their decision to leave the muck. "The time was past for asking the white folks what to look for outside that door. Six eyes were questioning God" (Their Eyes were Watching God, 235). Therefore the title and the word "God" incorporates a double, yet contradictory meaning: there is the God to whom we look for answers and pray for help and there is the other God, the cruel, false god who definitely needs watching.

As a young girl Janie is confronted with her grandmother's desire that Janie have everything she did not have. This the first stage of Janie's development when she is totally under Nanny's control. Janie doesn't understand why she is marrying ancient Logan Killicks but listens to her grandmother. To Nanny "being married is just being like white folks. It will protect Janie and help her to achieve certain middle class values, particularly since Logan has 60 acres of land and will not beat her"( Their Eyes were Watching God, 28). Although an independent woman herself, Nanny becomes, as Lillie Howard says "The chief spokesman for prosaic materialism" because of her existence with the white world. "She tells Janie, "Honey, de white man is de ruler of everything as fur as Ah been able to find out,"( Their Eyes were Watching God, 29) and what she wants for Janie is a life that is protected from, as well as a position that is safely within the framework of that culture. She uses a version of the tale, "Why the Sisters in Black Works Hardest" in which the "de white man tells de nigger to work and he takes and tells his wife,"( Their Eyes were Watching God, 30) she tries to make Janie understand. Yet Logan treats Janie exactly like the black man in the folk tale. The life that Nanny wants for Janie is the life that she saw the plantation owner's wife had: "ah was born back due in slavery so it wasn't for me to fulfill my dreams of what a woman oughta be and do" (Their Eyes were Watching God, 31).

Nanny dies before Janie runs with off Jody Starks, but it is he who secures Nanny's dream for Janie. Nanny's basic materialism is transformed into Jody's bourgeois aspirations. Jody is an example of the "Black Bourgeoisie" who believed that acquisitions of wealth and status would, in some way make them closer to the white culture which taught them being inferior. In the all black community of Eatonville, Jody quickly rises to success, becoming what one French sociologist termed a "colored Babbit." It is important to note that Janie did not leave Logan for Jody because of any material gains. She went because of a sense of adventure and because she was sure "the change was hound to do her good" (Their Eyes were Watching God, 54). At this point Janie begins to make choices concerning her own life.

Jody is a hard working, ambitious person and basically good natured, but the bourgeois and conventional in the way that he sees the world. He gains many possessions, the finest of these being his wife. He believes, as Nanny did, that the life for Janie is one in which she can "class off." Jody is confused by Janie's desire to thwart his attempts to put her "on the porch." The notion is that Janie, being the mayor's wife, should act more like a white woman Jody, like the Black bourgeoisie "who strove to make themselves over in the image of the white man," wanted to change his community into one which would be comparable to the white town up the road. The "white" in the Eatonville section is striking. Jody builds a "gloaty, sparkly white" house (Their Eyes were Watching God, 75) in the tradition of the old plantations and a large white porch for Janie to sit on. "He buys a street lamp for the town although some felt it a useless notion (Their Eyes were Watching God, 73). He does not understand Janie's disillusionment with their relationship because he did what he promised- made a "big woman" out of her. Although at this stage Jody has a greater identification with white middle class values than Nanny did, his power over Janie is less complete.

Janie's values are different from Jody's and what she wants is a spiritual partnership which has nothing to do with material things. "She got nothing from jody except what money could buy, and she was giving away 
what she did not value" (Their Eyes were Watching God, 118). Janie realizes that the life determined for her by Nanny which she lived with Jody was not for her. "(Nanny) was born in slavery time when folks, dat is black folks, didn't sit down ant timedey felt lak it. So sittin' onporches lak de white madam looked like a mighty fine thing tuh her ....So ah got to de highsckool lak she told me, but phoeby. Ah done nearly langiuished tuh death up dere" (Their Eyes were Watching God, 172). Janie has been living a life that was not her choice and with the death of Jody, she is determined to follow her own judgment. She has found out what love is not and that leads her to make a positive step towards Tea Cake and spiritual fulfillment.

Even after Janie goes with Tea Cake to the muck-which unlike the town is rich and black and big and free-she still must deal with the white world seen through the eyes of the mulatto Mrs. Turner. This woman exemplifies the final stage of white identification; idol worship. Of the three characters Mrs. Turner has the least effect on Janie: her main function is to shoe how wrapped an individual can become when she chooses the white man as her God. Janie's Caucasian features, which are incidental to her, become paramount to Mrs. Turner. She separates Janie and herself from dark ones like Tea Cake. Janie does not understand why this s important and in answer to Mrs. Turner's suggestion that they "class off," Janie replies "us can't do it. We'se a mingled people and all of got back kinfolks as well as yeller kinfolks"(Their Eyes were Watching God, 210). Mrs. Turner is horrified that Janie lets her witness be "defiled" by Tea Cake's blackness, because Mrs. Turner had defined white features and now is prepared to worship them in anyone who fits this description.

After Janie and Tea Cake leave the muck during the hurricane, they end up in Palm Beach. Since Tea Cake has been bitten by a dog while saving Janie from the flooding waters, they remain in a hotel for few days attending to Tea Cake's wounds. Finally Tea Cake wanders out to find out what has happened to his friends. While he is out on the streets of Palm Beach, he encounters two white men with guns who force him to recover and bury the victims of the flood. When he objects, one man shoves the rifle in his face and says"Git on downroaddere, suh! Don't look out somebody'll be buryin you! (Their Eyes were Watching God, 252). Then Palm Beach incident which has been viewed as an isolated example of racial injustice, appears in light of this analysis to be a concrete representation of what has been happening all along: the imposition of a dominant culture on an oppressed group, where the oppression is physical or psychological. Roger Rosenblatt noted that Tea Cake and Janie flourish only when they avoid the white world. This world implies white cultural values as well. When Janie and Tea Cake are pushed off the bridge in the storm to make room for the white folks and later in Palm Beach where Tea Cake is forced to throw the black corpses in a pit while he buries the white ones, we see their lives violated by white world; yet, equally destructive to their sense of well-being are the Mrs. Turner's and the materialistic considerations in the Eatonville community Janie resists these pressure and looks to Tea Cake and their love so that their soul can crawl out of its hiding place(p. 192)

Through their love and spiritual partnership, Tea Cake and Janie find the alternative to the white culture which is not only hostile and unattainable, but also stale and confining. They are not like Mrs. Turner; they make no distinctions concerning the folks. They bring the West Indians into their group of friends, and their house is a centre of activity. Unlike the big, white house in Eatonville which become a centre by power and fear, Tea Cake and Janie's place on the muck is a centre fashioned from love. Even as the storm threatens to break up this close-knit community, Janie and Tea Cake retain allegiance to the folk culture and the black world.as their Bohamian friend Lias leaves the ladies, he tells them "If ah never see you on mo' on Earth, Ah'll meet you in Africa" (Their Eyes were Watching God, 231). They will not meet in the cold, hard heaven of the white man; they will find each other in the rich, black fields of their African heaven.

When Janie returns o Eatonville after Tea Cake's death, without him and without the "fine cloths," she left with, she feels no need to justify herself to the community. Perhaps they think Tea Cake stole her money and left her for another woman (which happened to one woman who turned her back on the community), bit Janie is satisfied that she knows the truth. She comes back in her overall to a house once filled with loneliness of Jody's dreams and now filled with the rich memory of Tea Cake's love. She shares this with Phoeby, not to explain her position to the community but because Phoeby is her friend. And Phoeby hears and learns "Ah done growed ten feet higher jus' listening tuh you, Janie. Ah ain't satisfied wid mah-self no mo.' Ah meanstuh make sam take me fishin wid him after this," (Their Eyes were Watching God, 284). The community of Eatonville showed her love was not, but by looking into herself, she found what it was, Janie's advice to the town is that they better stop watching "God" and find out what their own lives are about before they go to Go. "Two things everybody's got tuh do fuh themselves. They got thu God, and they got thu find out about livin' fuh theyselves." (Their Eyes were Watching God, 285).

Commenting on the focusing title and significance theme of the novel Bell Hooks observes: Like many readers I have often thought Their Eyes Were Watching God most fascinating because of the way it challenges conventional sexist notions of woman's role in marriage and romantic love, insisting on the importance of female selfactualization. I too have celebrated Hurston's fictional portrait of love between a black woman and man. Critical attention has necessarily focused on these aspects of 
the novel. So intensely, however, that readers are inclined to overlook Hurston's concern with the construction of 'female imagination' and the formation of a critical space where woman's creativity can be nurtured and sustained. These concerns radically inform the structure of Their Eyes Were Watching God and its narrative direction. They can be fully addressed only if readers no longer centralize Janie's relationships with men. Strategically, the focus on romance is a device Hurston uses to engage reader's while subtly interjecting a subversive narrative.(Hooks, 245)

Hurston's passion for the folk tale which captivates audiences by sharing a story cast in terms of which appear familiar, coupled with her sense that stories were most interesting when lies masked truth, greatly influenced by her writing style, Barbara Johnson comments on this strategy regarding her passion and her magic:

If, as Hurston often implies, the essence of telling 'lies' is the art of conforming a narrative to existing structures of address while gaining the upper hand, then Hurston's very ability to fool us into thinking we have been fooled -is itself the only effective way of conveying the rhetoric of the 'lie'. (Johnson, 245)

Much of Hurston's magic and power as a writer centers on her incredible ability to manipulate multiple plots in a single narrative. Her insistence on playful subterfuge is often missed by readers of Their Eyes Were Watching God who sees the novel as conventional linear narrative weakened by textual gaps.

Unlike the conventional third person narrator who assumes a privileged distance from the story, Hurston's narrator is engaged, familiar and intimate. The tone of the narrator uses is similar to Janie's even though it is a more sophisticated voice. Some critics see Hurston's use of third person narration as a gesture which undermines the development of Janie's voice. Mary Helen Washington assumes that "Hurston was indeed ambivalent about giving a powerful voice to a woman like Janie who is already in rebellion against male authority and against the role prescribed for women in a male-dominated setting. Had the story been told in Janie's fictive voice there would have been little or no space for the inclusion of a wide range of folklore and folk wisdom much of which surface in dialogues between characters Janie would not have been in a position to hear" (Washington, 251). Hurston's skillful repression of Janie's voice never jeopardizes its significance. Even though readers do not hear her voice in the courtroom scene, we learn that she moved her audience, that she achieved the desired effect. Third person narration does not deflect attention away from that achievement that women must come to voice to be fully self-empowered. Third person narration calls attention to Hurston's authorial voice, highlighting the importance of writing.

Zora Neale Hurston could easily have become a renowned oral story-teller but she chose writing. Their Eyes Were Watching God celebrates story-telling as imaginative work that can serve as the foundation for the development of a written story. It is this fictive art form that most influenced Hurston's work. Hence the importance of her fictive opposition to black male domination precludes female participation in the oral-story telling. Men, Hurston suggests, are psychologically unable to be existentially self reflective about masculinity. In Their Eyes Were Watching God, masculinity is seldom celebrated and often mocked. There are certain correlations between her strategy and the literary tactics Virginia Woolf employs in A Room of One's Own. In both works the characterization of men is double edged and ironic. Hurston's portrait of Joe Starks is initially flattering, becoming progressively negative as his character unfolds later. Despite social superiority, men in Their Eyes Were Watching God look from afar, close up their flaws and failing surface. They are preoccupied with representation, obsessed with appearances. Janie hardly notices her long hair and never focuses on physical beauty. She is attracted to men who behave in a manner that appeals substantially. Ultimately Hurston's fictional portrayal suggests that men lack substance.

Hurston's characterization of males and females often suggest that women are possibly the superior gender. Janie intervenes in male conversation to challenge the notion of male superiority. Claiming to be on intimate terms with God she asserts "He tale me hoe surprised he was 'bout y'all turning out so smart after Him makin 'yuth different'(Their Eyes were Watching God, 284). Using her fiction to denounce expressions of masculinity associated with coercive domination, she challenges the accepted belief that the male who is best able to provide material possessions is that most desirable companion. New paradigms for heterosexual bonding are suggested via the characterization of tea Cake, in many ways an anti-masculine man with no desire to dominate others. Even though he has sexist attitudes, they are not the basis of his relationship with Janie. From the onset of their romantic bonding, Tea Cake introduces a model of heterosexual bonding base on reciprocity and mutuality.

Despite the varying ideological persuasions of its authors, recent criticism on Zora Neale Hurston's Their Eyes were Watching God has almost been unanimous in its assumption that Janie Crawford achieves a powerful and independent cultural voice as a result of her experiences. Critics also agree that Janie's achievement of voice is unquestionably a key factor in her eventual self-possession. Barbara Johnson, for example argues that "Janie's increasing ability to speak grows out of her ability not to mix inside with 
outside"(Johnson, 173). In a similar way Cherry wall suggests that "Janie's self-discovery depends on her learning to manipulate language. Her success is announced in the novel's prologue when, as a friend listens in rapt attention, Janie begins to tell her own story." A third example of the conflation of the achieved voice and studied self possession is offered by Missey Dehn Kubitschek, who believes "Janie discovers her own soul only through the art of storytelling, thus intimating the artist's responsibility to, and dependence on, the larger community"(Kubitschek, 110). Finally it is pertinent to note here that the focusing theme in the novel is revealed in the soul agonizing experiences of her life with husbands who could never rise above the sexual politics with all its designs and mechanism that subvert all the pure feelings and emotions of a woman seeking pure love.

\section{References}

[1]. Barbara, Johnson. Moving Beyond Boundaries: Black Woman's diasporas, Vol.-2. Washington Square: New York, 1995

[2]. Black-Burn, Regine. "in Search of the Black Female Self:African American Women's Autobiographies and Ethnicity." In Estelle C. Jelinek, ed. Women's Autobiography: Essays in Criticism. London: Indian University Press, 1980.

[3]. Cornillon, Susan K, ed. Images of Women in Fiction: Feminist Perspective. Ohio: Bowling Green University Press, 1972.

[4]. Davis, Angela. Women, Race, Class. London: The Women's Press, 1981.

[5]. Ferguson, Mary Anne. Images of Women in Literature. Boston: Houghton Mifflin, 1973.

[6]. Gates, Henry Louis. The Signifying Monkey: A Theory of African American Literary Criticism. New York: Oxford University Press, 1981.

[7]. Hemanway, Robert. Zora Neale Hurston, A Literary Biography. Urban III: University of Illinois Press, 1977.

[8]. Hooks, Bell. "Zora Hurston: A Subversive Reading." Moving Beyond Boundaries: Black Womens' Diaspore, ed. Carole Boyce Davis. Washington Square: New York Press, 1995.

[9]. Hurston, Zora Neale. Their Eyes were Watching God. Philadelphia: J.B. Loppincott Co, 1937.

[10]. I Love myself When I am Laughing."Zora Neale Hurston: A literary Biography, ed. Robert E Huston. Chicago: University of Illinois Press, 1997.

[11]. Jelinek, Estellec C, ed. Women's Autobiographical essays in Criticism. Bloomington:Indian University Press, 1980.

[12]. Kubtschek, Miss Dehn. "To De Horizon and Black: The Female Quest in "Their Eyes Were Watching God. BALA 17.3, 1983. 109150 .

[13]. Tate, Claudia, ed. Black Women Writers at Work. New York: Continuum Publishing Co., 1983.

[14]. Wall, Cherry. “An interview with Maya Angelou, womens". Autobiography: essays in Criticism, ed Estelle C. Jelinek. London: Blomington University. 59-67.

[15]. Washington, Mary Helen. "I Love the way Joanie Crawford left her Husband: Zora Neale Hurston Emergent Female Hero," Invented Lives: Narratives of Black Women. Doubleday: New York Anchor, 1987.237-254 